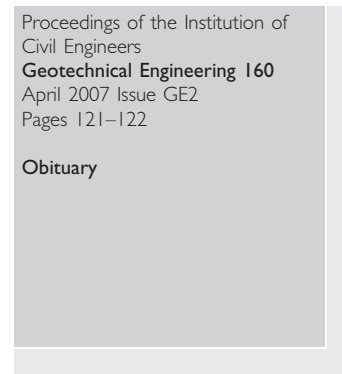

\title{
Obituary: Kenneth Wilson Cole
}

Ken Cole, who died on 9 January 2007, had a profound influence on the way in which geotechnical design is now undertaken in the UK. His particular contribution was to raise and set the standard of investigation and design to what is now accepted as the norm for good practice. As such he is one of the unsung heroes of British geotechnical engineering.

Ken first joined Ove Arup \& Partners in 1961 and worked in a structural engineering group alongside John Burland designing the deep basement for Britannic House (now Britannic Tower) in the City of London, one of the deepest, if not the deepest, basements at that time. Contemporaneously, Fred Butler was operating on his own, holding 'surgeries' in geotechnical design for Arup's structural engineering groups. Their success necessitated expansion and with Ken joining Fred in about 1964, the foundations of the first consultant-led geotechnical design group were laid. Hitherto geotechnical design was almost entirely undertaken by site investigation contractors, but competitive tendering for site investigations often led to minimal investigation with conservative design recommendations.

Both Ken and Fred appreciated that it was essential for the designer to assume much greater control of geotechnical processes, especially with the advent of increased foundation loads and deeper basements. Site investigations became firmly based on thorough desk studies. The results were discussed in a new interaction with structural engineers to provide an economical foundation design. Emphasis was placed on careful specification of the works by specialists and the need for them to supervise foundation construction. Although this approach is now accepted as the norm, it was nevertheless exceptional in the 1960's.

Ken and Fred Butler, in their commitment to raise standards, drafted Arup's own specifications for site investigation, laboratory testing, pile inspection and load testing, and for the construction of piling, earthworks and diaphragm walls etc. Many of these documents now form the basis for National Specifications and British Standards. In that respect alone, Ken made an outstanding contribution to British geotechnical engineering and certainly helped make Arup Geotechnics the force for good that it is today. Ken's dedication to raising standards was maintained throughout his career-in the last few years before he retired, he was a core member of the site investigation Steering Group set up by ICE, producing Without Site Investigation Ground is a Hazard and associated

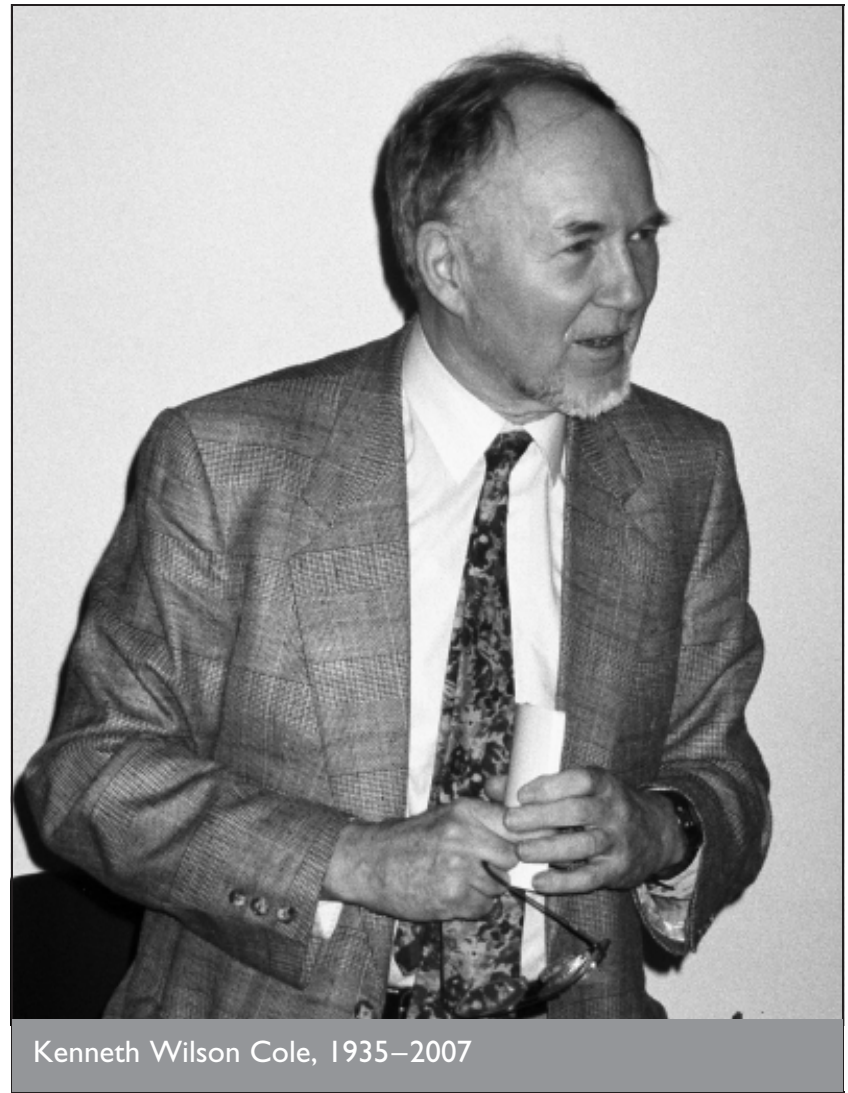

documents. Many of the case histories cited were drawn from Ken's past experiences.

In the late 1970's Ken led teams of bright young geotechnical engineers in the design of road embankments on soft alluvium at Queenborough, Sandwich and Dublin using systematic techniques of prediction and monitoring that we would now call the observational method. His prowess in soft ground was put to the ultimate test in his design for the approach embankments for the highway bridge over the River Shannon, built to relieve the chronic traffic bottleneck in the centre of Athlone. These were constructed on soils which rank among the weakest in the world. The project could not have started without the Ken's ability to identify and quantify methods of embankment construction that in 1979 were innovative, and his determination to support, at every stage, their adoption on a very difficult site in the middle of Ireland. He persuaded the National Roads Authority and the Chief Engineers of Westmeath and Roscommon (whose counties the bridge linked) 
that, contrary to the prevailing opinions of local specialists in soil mechanics, it was not only technically feasible, but could be built by local authority direct labour using stability charts. And so it was.

One of the first projects to benefit from the enhanced ground investigation standards and approach introduced by Ken was the Gateshead Western Bypass in the late 1960's/early 1970's, and one in which the Channel Tunnel Rail Link (CTRL) had its roots. A major problem was the interpretation of old mining records, then somewhat in its infancy and one that required considerable detective work. In one instance Ken discovered that the use of the same name for a seam did not necessarily indicate continuity-when the first high-value seam had been worked out, a little deception had been practised by applying the same name to another seam! Such was the volume of geotechnical work in the north-east that enquiries as to Ken's whereabouts frequently generated the response 'Cole's to Newcastle'.

Ken put his mining studies and the treatment of old mines to good use in leading a team evaluating the stability of old limestone mine workings in the Midlands and the development of innovative solutions for their stabilisation. The mines had been abandoned in the 18th and 19th centuries when the limestone they provided was no longer needed as flux in the production of iron. Surface collapses in the form of crown holes and subsidence were becoming an issue and creating housing blight. Ken led a Black-Country-wide study of the risk of collapse. Together with Bill Ward, he hit upon the concept of using colliery waste to fill the mine voids, thus releasing two sites for development: the site above the mine and the site of the colliery dump. The waste was slurried to the consistency of porridge, which amongst other epithets was given the title 'rock paste'. This could be pumped over considerable distances and into the offending mines via boreholes, from where it would flow to fill the voids. Many mines were successfully treated in this way through Dudley, Sandwell, Walsall and Wolverhampton.

Ken's knowledge of the problem as it affected the West Midlands and parts of Shropshire became encyclopaedic and it was a recognition of this knowledge, allied with Ken's dedication and commitment to solving the problems faced by the people living and working above the mines, that impressed the leaders of the affected Boroughs so much. Ken was to become known as 'Mr. Limestone' to many in the Local Authorities, and that respect is still shared by those who worked with him on the project.
Ken published papers across the full breadth of his wide experience in geotechnical design and construction. He was author of Foundations a concise, informative and practical volume in the ICE Works Construction Guides. He was also on the editorial advisory board of Ground Engineering from 1981 to 1996 , serving as chairman from 1990.

It was fitting that his contribution to British geotechnical engineering was recognised in 1992 by the award of the somewhat rare Skempton medal by the British Geotechnical Society (BGS). Some 20 years previously, in 1972, Ken had been awarded the BGS prize for his paper on the uplift of piles driven in groups, no mean achievement since prizes at that time were almost invariably awarded to academics.

Probably Ken's greatest achievement, and one which is a fitting memorial, was his very influential role in the route selection for CTRL. Ken was a passionate railway buff, as anyone who travelled by train with him soon realised. His detailed knowledge of the historic railway network in the UK, allied to his geological, geotechnical and topographical skills, enabled him to propose a route which reduced to a handful the number of existing dwellings affected, and served to help regenerate the north Thames marshes in the area now known as the Thames Gateway. His knowledge and dogged persistence made sure that the best route was selected. It is no exaggeration to say that the route finally chosen was Ken's route. It is a matter of great sadness that he did not live long enough to see the formal opening of his route into St Pancras in its entirety.

Ken took early retirement in 1995 due to ill health prior to a long battle with Parkinson's disease, in which he was nobly supported by his wife Gwen, their daughters Alison and Anna, and their families, including three grandchildren.

Ken was passionate about the engineering that he did, but he was equally passionate about the need to pass on the experience to his younger colleagues. His rigour and dogged thoroughness in critically reviewing reports of those in his charge was held in some awe and trepidation. However, it was this determination not to accept second best that won him the respect of colleagues and clients, and it is a legacy that in no small measure he has passed on to the profession as a whole. 